Information was given of the detailed plan prepared by the Association for Unesco to facilitate the distribution of films to universities. The purpose is to prepare a select list of films which could be used in first-or second-year university courses and of which it is possible to supply copies. This is an experimental project and the number of subjects to be covered and the number of films to be selected is limited. In co-operation with the International Council of Scientific Unions, a list of subjects has been prepared, reported Mr. B. Chibnall (Great Britain) the director of the project. The list includes subjects in botany, zoology, geology, chemistry and physies.

The International Film Library has been set up in Brussels, during the past year. It is having some initial troubles, but the Belgian Government has given a generous grant and premises. Among the directors are Mr. Edgar Anstey and Mr. John Maddison (both of Great Britain).

Among other decisions taken at the congress were to investigate the possibility of compiling and having published an international multilingual standard reference journal and vocabulary of scientific cinematography, and to standardize film catalogues. An offer by the Moroccan Government to investigate the possibility of setting up a distribution centre in Africa for scientific films was accepted. Two newly elected member countries of the Association are the United States and North Korea. This brings the total of member countries to twenty-seven, with three corresponding member countries.

The new officers of the Association are as follows: President, Edgar Anstey (Great Britain); Vicepresidents, J. Jacoby (Poland), S. Okada (Japan), R. Whaley (U.S.A.), A. Zgouridi (U.S.S.R.); Hon. Secretary, Mohammed Afifi (Morocco); Hon. Treasurer, Vladimir Vaclavek (Czechoslovakia).

The editor of Scientific Film, the official organ of the Association, is Mr. Maurice Goldsmith, c/o The Scientific Film Association, 55a Welbeck Street, London, W.l. The 1962 congress is to be held in Warsaw, and the 1963 congress in Rome. M. Goudsmitr

\title{
EDUCATION IN EMERGENT COUNTRIES
}

$\mathrm{F}^{\mathrm{O}}$ ORMERLY an outstanding educational administrator in New Zealand and now his country's Ambassador to France and permanent delegate to Unesco, Dr. C. E. Beeby presented an interesting paper on September 5 to Section L (Education) of the British Association for the Advancement of Science meeting at Norwich. The paper was based on Dr. Beeby's experience with the growth of educational services in newly developing countries, and especially Western Samoa, but also drew from his wide acquaintance with the evolution of educational systems in Western countries.

Dr. Beeby showed that, while it has taken England a hundred years to work out a system of universal primary education fairly well adapted to the needs of the community and to the varied capacities of the

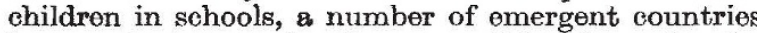
is now trying to do the same thing in a decade. At first sight it might appear that, with Western aid and benefiting from Western experience, they could leap the century and establish straight away something approaching a good modern type of classroom without having to plod through the stage of dreary formalism that marked the first fifty years of the Western system of compulsory schooling.

The position is not as simple as this, and the 'expert' advising an emergent country on its primary school system finds himself in the position of a butterfly teaching the chrysalis how to fly. There is an intermediate stage which must be gone through before some of his advice is of much significanco. Dr. Beeby became aware of this sixteen years ago when he had some responsibility for the control of two education systems that were, at that time, at least half a century apart. $\mathrm{He}$ found himself, without any sense of inconsistency, encouraging in Western Samoa the introduction of the formal educational practices which he had for a long time been combating in Now Zealand. This led to the conception of stages of development in the lifehistory of an education system, stages through which all systems, at least of a certain type, must pass, and which, though they may be shortened, eannot be skipped.
The inability of a primitive type of school system to profit immediately from all that has been learned about modern teaching methods is in no way due to any innate inferiority of either children or teachers in emergent countries. It depends primarily on two professional factors-the level of genoral education of the teachers in the system, and the amount and kind of professional training they have received. On this basis the development of an education system could be roughly divided into three stages: (I) 'dame school' stage, where teachers are ill-educated and untrained; (2) stage of formalism, where they are ill-educated but trained; (3) stage of meaning, where they are relatively well educated and also trained. At the dame school stage the syllabus consists of little but mechanical drill on the three $R$ 's and the memorizing of relatively meaningless symbols. The unsophisticated and untrained teacher turns naturally to formal mothods of teaching, and the real weakness of the teaching at the dame school stage is that it is confusedly and inefficiently formal. It has all the defects of formalism and none of its virtues; it is formalistic in spirit without having form.

At the other end of the scale the main characteristics of modern education, in spite of its failings, are the attempt to give the child a deeper and wider understanding of the meaning of the symbols with which he works. Practice in a good modern school is free, informal, and apparently 'natural' ; but it is based on a complex and sophisticated structure of theory, and, to succeed, it demands teachers who are both well-educated and well-trained. This is a long step from the ill-edueated and untrained teacher at the dame school stage, and in between must inevitably come the stage of formalism where teachers are still ill-educated but are trained. For sheer formlessness the only remedy is more form, however much one may dislike formalism as such in education.

The freedom and informality of the modern classroom depend on the teacher being sure of himself and of his subject-matter, and a teacher who is teaching at the very limits of his knowledge can have no sense of security if he or his class wander beyond the bounds of a tight official syllabus or the paste- 
board covers of the one official text-book. The only questions he can allow are those he asks himself, for they are the only ones of which he can be sure of knowing the answers. So the classroom must become formal. At the stage of formalism, symbols have more meaning for children than at a dame school stage, but it tends to be a narrow and restricted meaning. Classroom facts and skills are thin disparate things that mesh poorly with one another and scarcely at all with the warm rich world of the child's personal lifo.

It is tempting to try to find a short cut from the dame school stagc or the lower levels of the stage of formalism to the best of modern teaching methods, but there seems little hope of this if the difficulty to be overcome is really the meagre education of the teachers who are themselves the products of the schools ono is setting out to roform. With help and advice, the stage of formalism can certainly be reduced in length, but the reform of a school system is a skilled and delicate business, where too much haste can create confusion, and where our own unanalysed experience may not always be the best of guides. The difficulty is increased by the fact that not all the teachers in a system at any moment have the same capacity to take up new and complex methods.

A new element of urgency has developed with the explosive demand for education in newly independent States that has been one of the striking characteristics of the past decade. The demand for education, indeed, has become a new political force in the world, a force that no democratic Government can long resist, and countries are sometimes driven to launch ambitious schemes of universal education before they have teachers with enough education to make them effective. Unless there is to be a great waste of effort and grievous disappointment with the results of popular education in emergent countries, there is urgent need for a scholarly study, from a new and practical angle, of the whole natural history of the educational systern and of the factors that help or retard its progress from stage to stage.

\section{EXPECTATION OF LIFE IN THE UNITED STATES}

\begin{abstract}
A RECENT report issued by the Metropolitan Life Insurance Co., New York, directs attention to the fact that the average length of life (expectation of life at birth) among industrial policy-holders reached a new record of 70.5 years in $1960 *$. This is slightly above the figure for 1959 , and only half a year greater than that for 1955. But although recont increases have been limited, long-term gains have been very impressive. Five years have been added to the average length of life of these policy-holders since 1946, ten years since 1937, and twenty-four years since 1909. In 1879-94, the earliest period for which data are available, the average lifetime was only 34 years-less than half that for 1960 .

The largest gains in expectation of life have occurred at the younger ages. Thus, at the age of 5, the figure for 1960 was 5.9 years greater than that two decades ago. At the age of 40 , the increase since 1940 has been $4 \cdot 3$ years, while at 65 the average future lifetime of those insured has been extended $2 \cdot 3$ years to its present level of $14 \cdot 2$ years.

* Metropolitan Life Insurance Company. Statistical Bulletin, Vol. 42 (June 1961): Voting Population at Record High. Recent Variations in Pnetmonia-Influenza Mortality. Longevity of Industrial Policy-

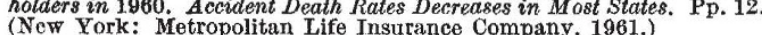

The longevity of American wage-earners and their families has increased more rapidly than that of the general population of the United States. In 1909, the expectation of life at birth of the industrial policy. holders was about six years less than that of the population as a whole. By mid-century the two groups were on a par; at present industrial policyholders have a slight advantage.

The long-term achievements in the conservation of life are accentuated by the very low death-rates now experienced in early life. Mortality of the coloured policy-holders, particularly beyond childhood, is considerably higher than that for whites. Among females, the rates for the coloured are at least double those for the whites from age 23 to the end of the childboaring period. Even though the difference is not as large for males, the ratio of mortality among them for the age-range 24-39 is more than $3: 2$.

Similarly, the average length of life is appreciably greater for white than for coloured policy-holders, and in each race is greater for females than for males. In 1960 , the expectation of life at age 5 years was $70 \cdot 7$ for white females, compared with $66 \cdot 2$ years for coloured females; the corresponding figures for males were 63.8 and 61.9 years.

\section{THE AMERICAN ACADEMY OF ARTS AND SCIENCES}

\footnotetext{
THE Records of the American Academy of Arts and Sciences 1960-1961* includes, as usual, the list of officers and committees, lists of members (including those elected May 10, 1961) with alphabetical index, the statutes and charter of incorporation, and reports submitted at the annual meeting. Special interest is given by the valedictory address of the retiring president, Kirtley F'. Mather, which, under the title "Assay and Perspective" reviews the activi-

* American Academy of Arts and Sciences, Boston. Records of the Academy (including new members elected 10 May, 1061), 1960-61. Pp. 157. (Boston, Mass.; American Academy of A'rts and Sciences, 1961.)
}

ties of the Academy during the four years of his presidency before appraising the present position of the Academy and its responsibilities and opportunities during the next decade. While it was doubtful whether the fullest possible use had been made of the Academy's new house, Mr. Mather thought that the success in developing its publication Daedalus as a journal of ideas and opinion had been outstanding and the Academy had been most successful in its development of conferences on topics of wide importance and interest.

As regards research, 119 grants totalling 91,903 dollars had been made in the past four and a half 